\title{
Determinants of Agricultural Productivity in India: An Econometric Analysis
}

\author{
Biswashree Tanaya Priyadarsini* and Chittaranjan Nayak**
}

\begin{abstract}
The main aim of this paper is to examine both short run and long run effects of various factors on agricultural productivity in India. The present study used the annual time series data covering the time period from 1980 to 2013. Johansen cointegration and vector error correction model are adopted in order to examine the objective of the study. The study has analysed the relative effectiveness of various factors like Irrigation (PGIA), Fertilizer (FERT), Electricity (ELCT), Private investment in agriculture (PII) and Non-product specific support to inputs (NPSS) on agricultural productivity. The cointegration results suggest that there is a long run equilibrium relationship between all the determinants and agricultural productivity. The vector error correction model indicates that there is long run causality running from PGIA, FERT, NPSS, ELCT, and PII to Productivity meaning that all the factors have significant influence on productivity in long run. However, as regards short run, only PGIA and PII have significant impact on agricultural productivity. The study suggests that the government should take initiative for non-product specific support to major inputs like organic fertilizer, power and irrigation and also promote private investment in agricultural sector to enhance agricultural productivity which will go a long way in development of agricultural sector.
\end{abstract}

Keywords: Agricultural productivity; Johansen cointegration; Vector error correction.

\subsection{Introduction}

Increasing agricultural productivity in a country like India has a lot of significance. It ensures food security, determines the growth prospects of the overall economy, and curbs labour migration. Agricultural productivity growth also helps in alleviating poverty in poor and developing countries.

\footnotetext{
*Lecturer in Economics, Rourkela Institute of Management Studies, Rourkela, Odisha, India. (Email id: btpriyadarshini@gmail.com)

**Corresponding author; Assistant Professor, Department of Economics, Ravenshaw University, Cuttack, Odisha, India. (Email id: chittaranjan.ru@gmail.com)
} 
As farms become more productive the wages earned by agricultural workers also increase. They get more money to spend on food as well as other products, which increase their welfare. Several studies suggest that India could eradicate its hunger and malnutrition and be a major supplier of food grain for the world by achieving more productivity comparable with other countries (Hazell \& Wood, 2008). In addition, an increase in a region's agricultural productivity implies a more efficient distribution of scarce resources. As farmers adopt new techniques, the more productive farmers benefit from an increase in their welfare while farmers who are not productive enough will exit the market to seek success elsewhere. So agricultural productivity is very much necessary for the development of Indian economy.

If we take a historical snapshot, in 1950's and 1960's, expansion of area under crop was the main source of growth. Subsequently, the contribution of cropped area to agricultural production declined, and increase in productivity became the main source of growth in agricultural production, especially during the Green Revolution period. However, the situation has turned adverse during the post-WTO period. The growth rate in output of all crops has declined from $2.73 \%$ in mature Green Revolution period to less than 2 percent in post reform period. Further within the crop sector all crops except sugar showed declining trend in the post-WTO period. This deceleration is very high in cereals, coarse cereals, pulses, oilseeds. This may be due to the fact that the new agricultural set up in the post WTO time has left little space for the green revolution strategies like subsidising new inputs, and farm mechanisation. When decelerating growth of agricultural productivity in India, researchers continue to be engaged in finding the key determinants of productivity. During the green revolution period, there was an intense debate on the relative effectiveness of price and non-price factors in raising agricultural productivity. Even in the post WTO set up where the role of price factors are quite limited, the debate still continues and the political economy around raising Minimum Support Prices(MSP) has not become irrelevant.

Under this backdrop, the present study makes an attempt to identify the main determinants of agricultural productivity by using cointegration and VECM for the long run impact and short run dynamics. The paper is structured as follows: Section 2 reviews related literature; Section 3 discusses data sources and methodology; Section 4 analyses the empirical results followed by the concluding remarks in Section 5.

\subsection{Review of Literature}

Many studies have tried to examine the determinants of agricultural productivity and which factors have greater influence on productivity. Some studies have analysed 
the impact of individual infrastructure items on productivity. For example, Barnes and Binswanger (1986) examined the impact of rural electrification on agricultural development. Based on data on 108 villages, the study finds that rural electrification has a direct impact on agricultural productivity through private investment in electric pumps. The study suggests that investment is necessary for infrastructural development. Dholakia and Dholakia (1993) analysed the sources of growth of Indian agriculture for three sub-periods during 1950-51 to 1988-89 for all crops. Growth accounting method was used for total factor productivity (TFP) analysis. The study revealed that modern agricultural inputs like fertilizer, HYV seeds and irrigation determined TFP. Rosegrant and Evenson (1995) have examined the sources of productivity growth and estimated the rates of return to public investment in agriculture. The study used Tornqvist-Theil index for computing total factor productivity for 271 districts covering 13 states in India during 1956-87. The study finds that investment in irrigation, extension and market have positive impact on total factor productivity. Public sector agricultural research and extension explains nearly 60 percent of total factor productivity growth over 1956-87 and private sector research and development has also significant contribution to total factor productivity growth.

Abugamea (2008) examines a dynamic analysis for Palestine agriculture production determinants by using time series econometric methods. The study has used Johansen- Granger cointegration procedures to forecast long run relationship among variables and uses error correction model (ECM) to check short run dynamics. The study finds that capital has significant negative effect on agricultural production and labor force has positive effect on agricultural production. The study did not mention the reason for why capital had negative effect. It has included only two factors as determinants, and ignored all other factors. In a district level study for Odisha, Nayak (2008) has also analysed the effect of rural infrastructure on land and labour productivity. The study developed a composite index for infrastructure by using principal component analysis and observed that the overall infrastructure index had significant impact on land and labour productivity, and out of all infrastructure items, irrigation and electricity had larger impact on productivity. Although it has selected determinants objectively, yet it was merely a cross section study based on secondary data, whose results cannot be generalised as such. In another study Nayak (2015) observes that, although rural infrastructure has overall positive impact on crop productivity, yet it leads to crop concentration in the state of Odisha, which has negative impact on productivity. Tripathi and Prasad (2008) analysed the impact of land, labour and capital on agricultural productivity growth from 1969-2005 in India. The study used Cobb- Douglas production function and finds all these factors had positive and significant impact on agricultural 
productivity growth. However, it has ignored the other factors which determine agricultural productivity.

Prabha et al. (2009) examined the trend of composite infrastructure index and technological variables such as fertilizer and HYV on agricultural productivity in Uttar Pradesh. It also analysed the impact of individual infrastructural indicators, composite infrastructure and technological variable on agricultural productivity. The study used multivariate regression of Cobb-Douglas function. The study found that agricultural productivity increased in Uttar Pradesh during green revolution period. There was sharp fluctuation in infrastructural growth. The study observed that fertilizer, area under HYV and infrastructure index had positive and significant impact on agricultural productivity.

Brownson et al. (2012) analysed the empirical relationship between agricultural productivity and some of the macroeconomic variables in Nigeria. The study has taken agricultural GDP as a ratio of total GDP as a proxy for agricultural productivity and some macroeconomic variables like total export, external reserve, inflation rate, per capita GDP, external debt, interest rate, nominal exchange rate, domestic saving, etc. The study used Engle- Granger and Johansen procedure for cointegration test to examine the long run association among time series variables. The study finds that total export, external reserve, inflation rate and external debt have negatively impact on agricultural productivity both in long run as well as in short run. But industrial capacity utilization rate and nominal exchange rate have significant positive relationship with agricultural productivity. On the other hand per capita real GDP positively influence productivity only in Error correction model (ECM).

Ahmad and Heng (2012) examined the impact of various determinants on agricultural total factor productivity growth in Pakistan by using auto regressive distributed lag model. The study finds that fertilizer, human capital (education of the farmers) and agricultural credit have positive significant impact on productivity growth. But this study has taken limited number of determinants and it is silent about the role of agricultural research and development, public and private investment in Pakistan. Adepoju and Salman (2013) examined the effect of rural infrastructure on agricultural productivity. The study used primary data and observed that farm size, household labor and number of years spent in school had all statistically significant positive impact on productivity.

Enu and Obeng (2013) examined the impact of macroeconomic factors on agricultural production in Ghana. Cobb-Douglas production was fitted by using the ordinary least square estimation technique. The study found that a one percent increase in labour force caused agricultural production decreased by $0.655 \%$, also a one percent increase in inflation caused agricultural production to increase by $0.0046 \%$ and a one 
percent increase in real exchange rate caused agricultural production to increase by 0.084 percent. Finally a $1 \%$ increase in real GDP per capita caused agricultural production to decrease by $1.058 \%$. The study, however, finds that inflation and real exchange rate have positive impact on agricultural production and labour force and real GDP per capita have negative impact on agriculture.

Singh and Kaur (2014) investigated the impact of infrastructure on agricultural production growth in Punjab during 1990-2011. The study has used exponential growth rate and inter correlation matrix for analysis. It finds that over the period of time the exponential growth rate in production and market arrivals of wheat were $1.35 \%$ and $2.79 \%$ respectively, and the paddy production growth and market arrivals were recorded as $2.60 \%$ and $3.07 \%$. The findings of the study also show that, number of regulated markets, total storage capacity, number of commercial banks and number of cooperative banks were positively related to each other to enhance agricultural production. A study from Nigeria, by using farm level data in Cassava based farms in Odogdolu local government area of Ogun concluded that the underdevelopment of infrastructural facilities leads to low agricultural productivity in the study area (Obayelu et al. 2014).

A quick look at some other major investigations on determinants of agricultural productivity, reveals that the items like increasing rural infrastructure and public investment in research, extension, information management, better management of rain water have been identified as the drivers of productivity (Chand et al., 2007; Bhalla and Singh, 2009; Reddy and Mishra, 2009; Vaidyanathan, 2010). The present paper adds some other factors like investment in agriculture and input subsidies on agriculture as determinants. As regards methodology, a large number of studies are basically based on regression analysis. Other methods of time series analysis like cointegration, vector error correction model (VECM), causality etc. have been used for various countries but not for India. Time series study is very much important for short run and long run analysis of determinant on agricultural productivity. So the present paper attempts to analyse the impact of input variables and infrastructure on productivity by using cointegration and VECM for the long run impact and short run dynamics.

\subsection{Data sources and methodology}

The present paper considers the following variables for the analysis.

(i) PGIA (Percentage of gross irrigated area): It is calculated as (Gross irrigated area/Gross cropped area)/100 (in hectare)

(ii) FERT (Fertilizer): It is calculated by dividing consumption of fertilizer (NPK) by Gross cropped area. The study has taken $\mathrm{Kg} /$ Hectare as the unit of measurement. 
(iii)ELCT (Electricity): Consumption of Electricity in Agricultural sector(gw/ha).

(iv) PII (Private Investment per hectare of land): It is calculated by dividing private investment with gross cropped area. The study has taken Rs Thousand/ Hectares as the unit of measurement.

(v) NPSS: Non-Product specific support to major inputs (Fertilizers, power and irrigation), it is input subsidies for farmers which are provided primarily through subsidizing fertilizers, irrigation water, electricity and seeds. The study has taken Rs thousand as unit of measurement.

The paper has used annual time series data covering a period 1980-2013 collected from various published sources like Directorate of Economic and Statistics, Ministry of Agriculture Govt. of India, Handbook of Reserve Bank of India, Ministry of Statistics and Programme Implementation, World Bank Data, and Agricultural Statistics at a glance (Various issues). The compiled data from indiastat.com are also used extensively. The study used land productivity as a measure of agricultural productivity and various factors like gross irrigated area (PGIA), Consumption of fertilizer (NPK), Consumption of electricity (ELCT), Private investment in agriculture (PII), Non product support to specific input(NPSS) for determinant analysis. All the variables are taken in original form after diagnostic testing and tests for heteroscedasticity, autocorrelation and multicollinearity.

\subsection{Results and Discussion}

To investigate the impact of different determinants on agricultural productivity (Yield) the empirical model is specified as:

$$
P D V T=f(E L C T, F E R T, N P S S, P I I, P G I A)
$$

The ADF and PP test performed unit root test in the variables. The null hypothesis is all the variables have unit root and the alternative there is no unit root. We have applied both ADF and PP test to estimate the order of integration of the variables. Table 1 reports the results of Augmented Dickey Fuller (ADF) and Phillips Perron (PP) test. The results of the unit root test show that the null hypothesis of unit root cannot be rejected in all variables in the level form. However, the first differencing the variables makes them free from unit roots at the convenient significance levels. Thus all the variables are integrated of order one, i.e. they are I (1). Since the variables are integrated of the same order, the study employs Johansen's cointegration to examine the long run relationship among the variables. The results of the cointegration and VECM analysis are reported in Tables 2 through 7. 
Table 1: Augmented Dicky-Fuller (ADF) \& Phillips-Perron Test

\begin{tabular}{|l|c|c|c|c|}
\hline \multirow{2}{*}{ Variables } & \multicolumn{2}{|c|}{ ADF Test } & \multicolumn{2}{c|}{ PP Test } \\
\cline { 2 - 5 } & Level & First Difference & Level & First Difference \\
\hline \multirow{2}{*}{ PDVT } & 1.90 & $-5.92^{*}$ & 1.13 & $-15.55^{*}$ \\
& $(0.99)$ & $(0.00)$ & $(0.99)$ & $(0.00)$ \\
\hline \multirow{2}{*}{ FERT } & 0.32 & $-4.77^{*}$ & 0.28 & $-4.77^{*}$ \\
& $(0.97)$ & $(0.00)$ & $(0.97)$ & $(0.00)$ \\
\hline \multirow{2}{*}{ PGIA } & -1.76 & $-4.01^{*}$ & -1.74 & $-4.11^{*}$ \\
& $(0.39)$ & $(0.01)$ & $(0.40)$ & $(0.01)$ \\
\hline \multirow{2}{*}{ ELCT } & 0.64 & $-4.82^{*}$ & 0.38 & $-4.91^{*}$ \\
& $(0.98)$ & $(0.00)$ & $(0.97)$ & $(0.00)$ \\
\hline \multirow{2}{*}{ NPSS } & 1.77 & $-7.28^{*}$ & 1.83 & $-7.29^{*}$ \\
& $(0.99)$ & $(0.00)$ & $(0.99)$ & $(0.00)$ \\
\hline \multirow{2}{*}{ PII } & 4.04 & $-8.09^{*}$ & 2.11 & $-8.87^{*}$ \\
& $(1.00)$ & $(0.00)$ & $(0.99)$ & $(0.00)$ \\
\hline
\end{tabular}

Note: * and ** indicates significance at $1 \%$ level \& $5 \%$ level respectively and the parentheses represent the $p$ values. $c \& t$ represent constant and trend.

Source: Authors' calculation using EVIEWS

Table 2: Cointegration Result

\begin{tabular}{|l|c|c|c|}
\hline $\begin{array}{c}\text { Hypothesized number of } \\
\text { Cointegrating Equation }\end{array}$ & $\begin{array}{c}\text { Max-Eigen } \\
\text { Statistics }\end{array}$ & $\begin{array}{c}\text { 5\% critical } \\
\text { value }\end{array}$ & Prob** Value \\
\hline None $(\mathrm{r}=0)$ & 42.07 & 40.07 & 0.0294 \\
\hline At most $1(\mathrm{r}=1)$ & 29.52 & 33.87 & 0.1515 \\
\hline At most 2(r=2) & 22.25 & 27.58 & 0.2075 \\
\hline
\end{tabular}
Note: Max-Eigen test indicates one cointegration at the 0.05 level
** denotes Probability Values (Mackinonn-Haug-Michelis, 1999)
Source: Authors' calculation using EVIEWS

It is noteworthy that on the basis of AIC lag length selection criterion, the paper uses lag one. We can see from Table 2 that the hypothesised number of cointegrating equations is ( $\mathrm{r}=0,1,2,3,4$ and 5). 0 means there is no cointegration among variables, that is our null hypothesis $\left(\mathrm{H}_{0}\right)$ and the alternative hypothesis is cointegration among variables $\left(\mathrm{H}_{1}\right)$. This is same as $\mathrm{r}=1,2,3,4,5$ meaning there are at most one, two, three, four or five cointegrating equations. To reject or accept null hypothesis, the paper has used the criteria of maximum eigen value with p-value less than 0.05 . When the MaxEigen statistic is greater than critical value we can reject our null hypothesis and accept the alternative hypothesis. Since the Max-Eigen statistic (42.07) is greater than the critical Eigen value (40.07) and the p-value is less than 5 percent, the null hypothesis $r=0$ 
is summarily rejected. Then we come down to the next row where null hypothesis is $r=1$, that means there is one cointegration among variables. Here Max-Eigen statistics (29.52) is less than critical value (33.87) and p-value is more than $5 \%$, so we accept the null hypothesis, i.e., there is one cointegrating equation among variables. Hence the variables are cointegrated or have long run association. When variables are cointegrated, we can run vector error correction mechanism (VECM), which has been attempted in this paper. The results of VECM model are presented in the Tables 3 and 4.

Table 3: Error Correction Estimation

\begin{tabular}{|l|c|c|c|c|c|c|}
\hline & D(PDVT) & D(FERT) & D(NPSS) & D(ELCT) & D(PGIA) & D(PII) \\
\hline \multirow{3}{*}{ CointEqn1 } & -0.118974 & $2.35 E-05$ & $-7.72 \mathrm{E}-05$ & -0.000883 & $8.74 \mathrm{E}-05$ & -0.049803 \\
\cline { 2 - 7 } & $(0.03017)$ & $(0.00016)$ & $(4.6 \mathrm{E}-05)$ & $(0.00093)$ & $(3.5 \mathrm{E}-05)$ & $(0.01578)$ \\
\cline { 2 - 7 } & {$[-3.94373]$} & {$[0.14284]$} & {$[-1.68627]$} & {$[-0.95448]$} & {$[2.47519]$} & {$[-3.15637]$} \\
\hline
\end{tabular}

Note: Dependent Variable: D (PDVT); Standard Error is in Parenthesis ( ) and t-value is in bracket [ ] Source: Authors' calculation using EVIEW

Table 4: VECM Estimation for Short run Analysis

\begin{tabular}{|c|c|c|c|c|c|c|}
\hline & D(PDVT) & D(FERT) & D(NPSS) & D(ELCT) & D(PGIA) & D(PII) \\
\hline \multirow{3}{*}{$\mathrm{D}(\operatorname{PDVT}(-1))$} & -0.498805 & $2.35 \mathrm{E}-05$ & -0.000168 & 0.003696 & -0.000227 & 0.017979 \\
\hline & $(0.13664)$ & $(0.00016)$ & $(0.00021)$ & $(0.00419)$ & $(0.00016)$ & $(0.07147)$ \\
\hline & {$[-3.65049]$} & {$[0.14284]$} & {$[-0.80934]$} & [ 0.88199$]$ & {$[-1.41715]$} & [ 0.25158$]$ \\
\hline \multirow{3}{*}{ D(FERT(-1)) } & -49.67262 & $6.83 \mathrm{E}-05$ & -0.045987 & 0.647231 & 0.061281 & -52.08834 \\
\hline & (45.2175) & $(0.00074)$ & $(0.06864)$ & (1.38692) & $(0.05291)$ & (23.6498) \\
\hline & {$[-1.09853]$} & [ 0.09173] & {$[-0.66994]$} & [ 0.46667$]$ & [ 1.15821$]$ & {$[-2.20248]$} \\
\hline \multirow{3}{*}{ D(NPSS(-1)) } & -103.1452 & -0.022688 & -0.124920 & -12.03747 & -0.134818 & -105.0308 \\
\hline & (145.088) & $(0.24626)$ & $(0.22025)$ & (4.45018) & $(0.16977)$ & (75.8846) \\
\hline & {$[-0.71091]$} & {$[-0.09213]$} & {$[-0.56717]$} & {$[-2.70494]$} & {$[-0.79411]$} & [-1.38409] \\
\hline \multirow{3}{*}{$\mathrm{D}(\mathrm{ELCT}(-1))$} & 6.038461 & -1.320389 & -0.014191 & 0.256434 & -0.003813 & -3.437649 \\
\hline & (6.79297) & $(0.79017)$ & $(0.01031)$ & $(0.20836)$ & $(0.00795)$ & $(3.55288)$ \\
\hline & [0.88893] & {$[-1.67103]$} & {$[-1.37611]$} & [ 1.23075$]$ & {$[-0.47976]$} & [-0.96757] \\
\hline \multirow{3}{*}{ D(PGIA(-1)) } & 803.0381 & 0.007198 & 0.469518 & 2.785059 & -0.062184 & 258.0240 \\
\hline & (206.499) & $(0.03700)$ & $(0.31348)$ & (6.33379) & $(0.24163)$ & (108.004) \\
\hline & [ 3.88882] & [ 0.19458] & [ 1.49777$]$ & [0.43971] & {$[-0.25735]$} & [ 2.38902] \\
\hline \multirow{3}{*}{$\mathrm{D}(\mathrm{PII}(-1))$} & -0.593714 & 0.739509 & 0.000468 & 0.008437 & -0.000340 & -0.135904 \\
\hline & $(0.35482)$ & $(1.12462)$ & $(0.00054)$ & $(0.01088)$ & $(0.00042)$ & $(0.18558)$ \\
\hline & {$[-1.67328]$} & {$[0.65757]$} & [ 0.86958$]$ & {$[0.77520]$} & {$[-0.81877]$} & {$[-0.73232]$} \\
\hline \multirow{3}{*}{ Constant } & 747.5731 & 4.061402 & 1.749587 & 24.96613 & 0.504052 & 531.8322 \\
\hline & (259.585) & (1.41373) & $(0.39407)$ & (7.96206) & $(0.30375)$ & (135.769) \\
\hline & [ 2.87988] & [ 2.87283] & [ 4.43982] & [ 3.13564$]$ & [ 1.65944$]$ & [ 3.91718$]$ \\
\hline
\end{tabular}

Note: Standard Error is in Parentheses ( ) and t-values are in bracket [ ] Source: Authors' calculation using EVIEWS 
Here productivity (PDVT) is the dependent variable. Tables 3 and 4 show long run and short run analysis respectively. The probability values are necessary to know the influence of different variables on land productivity. So for probability value we generate system equation by taking only the second column of Table 4, because PDVT is our dependent variable and then estimate equation by applying least square method.

The system equation is written as follows:

$$
\begin{aligned}
\mathrm{D}(\mathrm{PDVT})= & \mathrm{C}(1) *(\text { PDVT }(-1)-738.632705456 * \mathrm{FERT}(-1)-199.915461788 * \mathrm{NPSS}(-1) \\
& +20.0573234044 * \mathrm{ELCT}(-1)+1840.40724278 * \mathrm{PGIA}(-1)+ \\
& 1.47280686871 * \mathrm{PII}(-1)-34491.5099304)+\mathrm{C}(2) * \mathrm{D}(\mathrm{PDVT}(-1))+ \\
& \mathrm{C}(3) * \mathrm{D}(\mathrm{FERT}(-1))+\mathrm{C}(4) * \mathrm{D}(\mathrm{NPSS}(-1))+\mathrm{C}(5) * \mathrm{D}(\mathrm{ELCT}(-1))+ \\
& \mathrm{C}(6) * \mathrm{D}(\operatorname{PGIA}(-1))+\mathrm{C}(7) * \mathrm{D}(\mathrm{PII}(-1))+\mathrm{C}(8)
\end{aligned}
$$

The result of this equation estimation is shown in Table 5 .

Table 5:Vector Error Correction Equation Estimation

\begin{tabular}{|l|c|c|c|c|}
\hline & Coefficient & Std.Error & t-statistic & Probability Value \\
\hline $\mathrm{C}(1)$ & -0.118974 & 0.030168 & -3.943735 & 0.0006 \\
\hline $\mathrm{C}(2)$ & -0.498805 & 0.136641 & -3.650489 & 0.0013 \\
\hline $\mathrm{C}(3)$ & -49.67262 & 45.21746 & -1.098527 & 0.2829 \\
\hline $\mathrm{C}(4)$ & -103.1452 & 145.0882 & -0.710914 & 0.4840 \\
\hline $\mathrm{C}(5)$ & 6.038461 & 6.792965 & 0.888929 & 0.3829 \\
\hline $\mathrm{C}(6)$ & 803.0381 & 206.4991 & 3.888820 & 0.0007 \\
\hline $\mathrm{C}(7)$ & -0.593714 & 0.354820 & -1.673281 & 0.1073 \\
\hline $\mathrm{C}(8)$ & 747.5731 & 259.5851 & 2.879877 & 0.0082 \\
\hline
\end{tabular}

Note: Dependent Variable: $D(P D V T)$

Source: Authors' calculation using EVIEWS

In the above equation, $\mathrm{C}(1)$ is the coefficient of cointegration model. It is also known as error correction term or speed of adjustment towards equilibrium. In VECM analysis there are two issues: long run causality and short run causality. To know about long run causality, we see the coefficient of $\mathrm{C}(1)$, that is -0.118 . It is also significant (see p-value in Table 5) at 5 percent level. So we can say that there is long run causality running from PGIA, ELCT, NPSS, PII, and FERT to PDVT meaning that all the independent variable has significant influence on productivity in long run. The short run impact of variables on productivity is shown by result of Wald test in Table 6. From Table 6 we see that except C(6)(Coefficient of PGIA) and C(7) (Coefficient of PII) we accept all the null hypotheses that means there are no short run causality running from FERT, NPSS, ELCT, to PDVT, meaning that in short run these variables have no 
influence on productivity. Only the PGIA and PII have significant influence on PDVT, meaning that there is short run causality running from PGIA to PDVT and from PII to PDVT. So that in short run only irrigation and private investment has significant impact on land productivity.

\section{Table 6: Result of Wald Test}

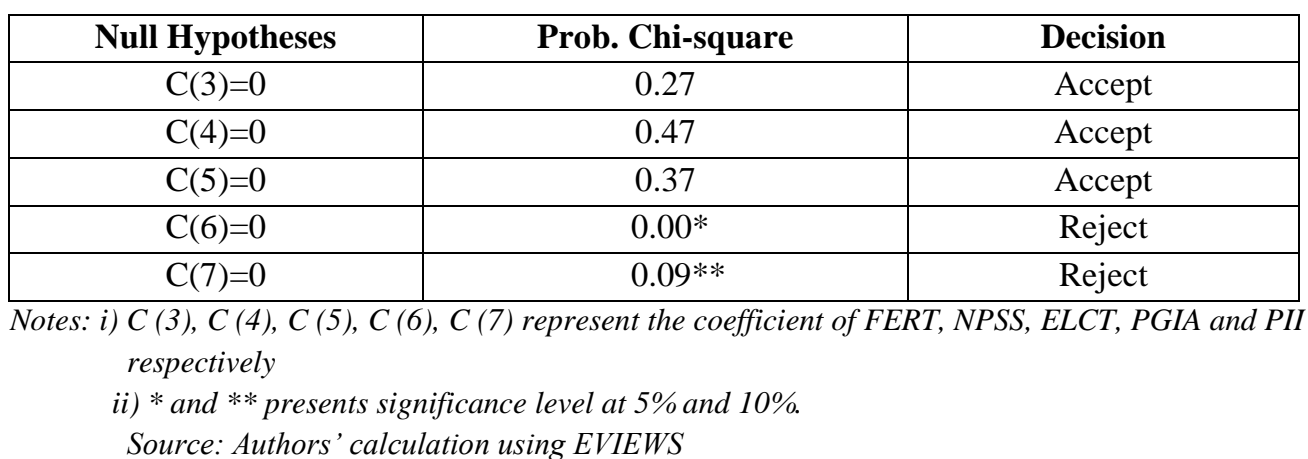

From the Table 7, we see that our model is very well because the residuals have no serial correlation, no heteroscedasticity and the model has normally distributed and that is desirable. Here the value of $\mathrm{R}^{2}(0.61)$ which is more than $60 \%$ and $\mathrm{F}$ statistics is also significant meaning that our model is fitted well. The study primarily investigates the determinant of agricultural productivity (Land) in India during 1980-2013. The result of the econometric analysis shows that there is a long run relationship between all determinants and land productivity. However, in case of short run only irrigation and private investment have significant impact on land productivity.

Table 7: Diagnostic Test of the VECM

\begin{tabular}{|l|c|}
\hline \multicolumn{1}{|c|}{ Statistics } & F Stat [prob.] \\
\hline Serial Correlation & $2.70(0.09)$ \\
\hline Heteroscedasticity Test & $8.14(0.77)$ \\
\hline Normality Test (Jarque-Bera) & 0.56 \\
\hline $\mathrm{R}^{2}$ & 0.61 \\
\hline $\mathrm{F}$ & 5.40 \\
\hline Prob (F-Statistic) & 0.00 \\
\hline
\end{tabular}

Note: Dependent Variable PDVT; Probability value in Parenthesis ( )

Source: Authors' calculation using EVIEWS 
This study is consistent with the studies of Infrastructure development affects the agricultural productivity in India in the long-run but not in the short-run (Zhang \& Fan, 2001). Improvement in human capital and infrastructure development has a significant positive effect on TFP of agriculture in the long-run. (Nadeem et.al 2011)

\subsection{Concluding Remarks}

The major objective of this paper was to examine the long run and short run impact various factors on agricultural productivity. The present study used the annual time series data covering the time period from 1980 to 2013. By applying advance time series techniques such as cointegration and Vector error correction model (VECM) the study found that the variables have long run long run association and in the long run they move together. The result of co integration indicates that the study used VEC model to know about the short run dynamics and speed of adjustment of the variables in the long run relationship. From VECM it is found that, among all the variables, only irrigation (PGIA) and Private investment (PII) have short run causality or these two determinants have short run impact on agricultural productivity but in the long run all determinants of our study have significant impact on productivity.

On the basis of its main findings the present study recommends that the government should provide better infrastructure for long run growth of agricultural productivity and invite private sector for better improvement and commercialisation of agricultural sector and also focus on sustainability without hampering the quality of land. It can be say that, growth of agricultural productivity and sustainability goes together. So that it is essential to focus on natural resource system comprising land, and water which form the production base of agriculture. The government should take initiative for more expenditure on non-product specific support to major input like fertilizer, power and irrigation and also promote private invest in agricultural sector to enhance agricultural productivity in the long run. Private investment and irrigation also played important role in long run as well as in short run to increase productivity, so the government should focus on access of electricity by providing more power to every rural and backward area of the country, where agriculture is the main source of livelihood. There is also a need to have more emphasis on irrigation system and rain water harvesting. Private investment in agricultural sector has a positive impact in long run, so the government should take initiative to encourage private investment also incorporate foreign direct invest in agricultural sector. 
52 | MANTHAN: Journal of Commerce and Management, Volume 4, Issue 2, Jul-Dec 2017

\section{References}

Abugamea, G. (2008). A dynamic analysis for agricultural production determinants in Palestine: 1980-2003. Proceedings International Conference on Applied EconomicsICOAE-2008 - Kastoria - Greece, 15-17 May.

Adepoju, A. A. \& Salman, K. K. (2013). Increasing agricultural productivity through rural infrastructure: Evidence from Oyo and Osun states, Nigeria. International Journal of Applied Agricultural and Apicultural Research. 9 (1\&2): 1-10.

Ahmad, K., \& Heng, A.T.H. (2012). Determinants of agricultural productivity growth in Pakistan. International Research Journal of Finance and Economics, Issue 95. Retrieved from http://www.internationalresearchjournaloffinanceandeconomics.com/ ISSUES/ IRJFE_Issue_95.htm

Barnes, F. D., \& Binswangner, P. H. (1986). Impact of rural electrification and infrastructure on agricultural changes, 1966-1980. Economic and Political Weekly, 21(1), 26-34.

Bhalla, G. S. \& Singh, G. (2009). Economic liberalisation and Indian agriculture: A state wise analysis. Economic and Political Weekly, 44 (52), 34-44.

Brownson, S., Vincent, I., Emmanuel, G. \& Etim,D. (2012). Agricultural productivity and macroeconomic variable fluctuation in Nigeria. International Journal of Economics and Finance, 4(8), 114-125.

Chand, R., Raju, S. S. \& Pandey, L. M. (2007). Growth crisis in agriculture: severity and options at national and state levels. Economic and Political Weekly, 42(26): 2528-33.

Dholakia, R. H \& Dholakia, B.H. (1993). Growth of total factor productivity in Indian agriculture. Indian Economic Review, 28(1), 25-40.

Enu, P, \& Attah-Obeng, P. (2013). Which macro factors influence agricultural production in Ghana. Academic Research International, 4(5), 333-346.

Hazell, P. \& Wood, S.(2008). Drivers of change in global agriculture. Philos Trans $R$ Soc Lond B Biol Sc, 363(1491), 495-515. 
Nadeem, N., Mushtaq, K. \& Javed, I.M. (2011). Impact of social and physical infrastructure on agricultural productivity in Punjab, Pakistan- A production function approach. Pakistan Journal of Life and Social Sciences, 9(2), 153-158.

Nayak, C. (2008). Physical infrastructure and land productivity: A district level analysis of rural Odisha, The ICFAI University Journal of Infrastructure, 6(3), 7-21.

Nayak., C. (2015). Crop diversification and land productivity in Odisha: Role of rural infrastructure. PRAGATI: Journal of Indian Economy, 2(2), 1-18.

Obayelu, A.E., Olarewaju, T.O., \& Oyelami, N.E. (2014). Effect of rural infrastructure on profitability and productivity of Cassava based farms in ODOGBOLU local government area, Ogun state, Nigeria. Journal of Agricultural Sciences, 59(2), 187-200.

Prabha, Goswami, K., \& Chatterjee, B. (2009). Impact of infrastructure and technology on agricultural productivity in Uttar Pradesh. Agricultural Research Review, 22(JanJun), 61-70.

Reddy, D. N., \& Mishra, S. (2009). Agriculture in the reforms regime. In D Narasimha Reddy and Srijit Mishra (Eds), Agrarian crisis in India. New Delhi: Oxford University Press.

Rosegrant, M.W., \& Evenson, R.E. (1995). Total factor productivity and sources of long term growth in Indian agriculture. EPTD Discussion Paper No.7, International Food Policy Research Institute, Washington, D.C., U.S.A.

Singh, P. \& Kaur, J. (2014). Role of infrastructure in the growth of agriculture in Punjab. IOSR Journal of Economics and Finance, 3(5), 17-20.

Tripathi, A. \& Prasad, R. A. (2008). Agricultural productivity growth in India. Journal of Global Economy, Retrieved from http://works.bepress.com/amarnath_tripathi/1

Vaidyanathan, A. (2010). Agricultural growth in India, role of technology, incentives, and institutions. New Delhi: Oxford University Press.

Zhang, X. \& Fan, S. (2001). How productive is infrastructure? New approach and evidence from rural India. EPTD Discussion Paper No. 84, Washington, D. C: International Food Policy Research Institute, Washington, D.C., U.S.A. 